\title{
GAMES THE GOVERNMENT PLAYS: FEDERAL FUNDING OF MINORITY ECONOMIC DEVELOPMENT
}

\author{
Otтo J. HetzeL*
}

\section{Introduction and Game Pian}

Little control or ownership of wealth-generating resources in the United States is in the hands of minority group members. ${ }^{1}$ In an avowed attempt to increase participation in the economic mainstream, ${ }^{2}$ a number of federal government programs have held out the hope of financial support for development of minority business enterprises. These programs have included those administered by the Office of Economic Opportunity (OEO), ${ }^{3}$ the Department of Housing and Urban Development (HUD), the Department of Commerce, ${ }^{5}$ and the Small Business Administration (SBA).$^{6}$ In every instance, pronouncements of specific thrusts to develop innercity minority business have been widely heralded. Some programs have included development efforts for rural areas as well, thereby assisting Indians and MexicanAmericans. In each case, however, the "getting" has been far from easy, and the "using" has been equally frustrating. This article will attempt to illustrate that the government's administration of these programs often constitutes a series of "games" imposed on those minority group members who attempt to utilize the financial

* Professor of Law, Wayne State University, and Associate Director, Center for Urban Studies. The author wishes to acknowledge the valuable assistance of Thomas Werner, a student research assistant, in the preparation of this paper.

${ }^{I}$ Industry distribution showed that most minority ownership was of retail businesses with personal service businesses second. There was little minority ownership of construction and manufacturing concerns. Nearly all of the minority businesses were situated in urban areas. SMall Business Admisistration, National SuRvey of U.S. Business I, 2 (I969). The "typical" minority businessman operates a onc-man personal service or retail shop in a central city area, and has annual gross receipts of $\$ 20,000$ or less. The comparable figure for other businesses is $\$ 50,000$. Only $3.25 \%$ of the nation's more than 5,000,000 small businesses are owned by members of minority groups, although such members comprise $15 \%$ of the nation's population. Hearings on the Economic Opportunity Amendments before the Subcomm. on Employment, Manpower and Poverty of the Senate Comm. On Labor and Public Welfare, 9Ist Cong., Ist Sess. 579 (1969) [hereinafter referred to as Economic Opportunity Hearings].

2 The federal government has developed several thrusts to expand minority involvement in the SBA's programs. Under the Johnson Administration these efforts were entitled "Project OWN." The Nixon Administration renamed them "Operation Mainstream" to stamp them with its imprint. Dedicated as these titles seem, it must be remembered that it is effectiveness-not tilles-that provides progress.

${ }^{3}$ The Office of Economic Opportunity distributed funds authorized under title I-D of the Economic Opportunity Act of I964, 42 U.S.C. $\$ \$ 2701-2981$ (I964), as amended, 42 U.S.C. $\$ \$ 2763-68$ (Supp. V, r970).

¿ HUD administers the Model Cities program, which is the colloquial name given the program authorized under the Demonstration Cities and Metropolitan Development Act of 1966, 42 U.S.C. $\$ 53301-13$ (Supp. V, I970).

The Department of Commerce's Economic Development Administration manages the program authorized under the Public Works and Economic Development Act of I965, 42 U.S.C. \$\$ $3121-26$ (Supp. $\mathrm{V}, 1970$ ).

${ }^{6}$ Small Business Act, I5 U.S.C. $\$ \$ 63 \mathrm{I}-47$ (I964). 
resources offered. A typical program may include some or all of the following games initiated by the government and often involving various gambits, variations, and other gamesmanship qualities which the government's bureaucracies have painstakingly, albeit unknowingly, constructed.

Initially the government begins the action with Come Play with $\mathrm{Me}$, a game that generally follows a consistent form. The government brings forth its development program and through brochures, pamphlets, public speeches, personal sell, and other similar techniques attempts to interest minority group members in playing-that is, requesting financial support. Promises are made, expectations are planted, and minority businessmen become eager to play.

Once the government has attracted the minority group member, it initiates a second game, See if You Qualify. This is the first of a long series of frustrations for the now recruited applicant as he attempts to successfully complete his quest. Often See if You Qualify is a long game. The government makes it very difficult for a minority businessman to find out if he is eligible. Eligibility also can be complicated if the goverment decides to impose Gotta Play with Those Guys (even if they don't want to play with you). In Gotta Play with Those Guys the minority businessman is forced to acquire a partner before he can proceed. The partner may have to be a private lending institution, a local government body, or both. The partner will, of course, extract a price for its "cooperation." The game ends, along with any hope of federal aid, if the minority businessman is not willing to or cannot acquire a partner. Another game that arises in conjunction with See if You Qualify is Gotta Bring Your Own Ball (even if you don't have one). Gotta Bring Your Own Ball requires that the minority businessman acquire a certain amount of private capital before he can qualify for a loan or a grant of federal money. If he fails to acquire that capital either on his own or from his partner, the games are over and he loses.

Should the minority businessman be successful at See if You Qualify, the government continues to play other games with him, although the tactics used can vary depending upon the program involved. For instance, the government often imposes Only One Game at a Time, thus prohibiting the player from participating in several government programs simultaneously. While one government bureaucracy may ask for multiple program involvement, another will invoke Only One Game at a Time. This tactic forces the minority participant to choose only one program, and the player then can use no other program's aid during the game.

Perhaps the most frequently imposed game is Change the Rules. This comes in two segments: specific rules are set by the government ${ }^{7}$ and agreed upon by the player; then, when the player begins to play under them, the government changes the rules. Change the Rules can result in the players' needing to renegotiate totally his relationships with government-imposed partners (often to his great detriment), to

\footnotetext{
${ }^{7}$ Rules can be set by statute, administrative regulations, policy issuances, guidelines, speeches, or contract.
} 
change his internal organization, or to amend his business operation. If he refuses to change, the practical result is often that he is prevented from participating further in government programs.

Another favorite government game seems to be No Mistakes Allowed. The player is allowed to play until he makes an error, whether major or minor. Sometimes it is better to make a major error, because no bureaucrat likes to admit he approved of aid to an applicant who turned out to be a real "loser." After the error the government often moves against the player in a concerted effort to drive him out of the program.

No administration of a government program is complete unless it involves Rig the. Game, with its many variations and gambits. Rig the Game occurs in threo forms. One involves use of time controls by the government. When a player falls behind the imposed schedule and time runs out, the player loses. Government time delays are also part of this ploy: it can delay action at certain stages of the program for so long a period that the player is forced to quit the game and search elsewhere for aid. In a second variation of Rig the Game, government aid is designed so that no player has enough money at any time with which to succeed. Sooner or later, he goes broke and loses the business. The government may also Rig the Game by promising to supply managerial and technical assistance to its players. In most cases this aid either is not given or is insufficient to impart the knowledge necessary to make the business successful. Sometimes when the aid is effective, the government "rewards" the initial success by using the tactic Withdraw the Aid or by rendering it ineffective by other means.

The ultimate result of these games is to provide the government with an opportunity to play You Fail. In You Fail the player becomes so discouraged that the government assumes his role and closes off the program to him. Near the end of this game, all player influence is eliminated. The government continues the program with other applicants attracted by Come Play with $\mathrm{Me}$-it seems to have an insatiable need for fresh players. Conversely, it is axiomatic that every administrator must have a program to administer.

During the development of the minority business the federal agency which has imposed the games acts as referee. Its decisions are final and no protest is allowed the player. Occasionally the player attempts to reverse roles and instigate a game called Legal Review. This game, however, usually results in further losses for the player, and little relief is obtained. There is usually an analogy here to "don't bite the hand that feeds you." The condition of servitude thereby involved can be a bitter pill to minorities using economic development to obtain their independence. Finally, even "success" in Legal Review comes far too late for the player who is out of business or, at the least, has lost control.

By attempting to work within the system, the minority businessman is required to play the government's games. When the minority businessman ultimately loses, 
he naturally feels embittered toward the system. If major improvements are not made in the government's attitude, and in its approaches to operation of its economic development programs, the economic condition of minority groups will become even more depressed. Traditional funding sources have not been adequate to give minorityowned or controlled business an opportunity to establish itself. The government must abandon its game playing, and take the initiative and the risks necessary to fund new ventures. Its current dependence upon the use of private lending sources, particularly as a way to escape taking risks, must be curtailed, for, in the area of financing, it is simply impractical to expect the private sector, which must be profitoriented, to underwrite minority developmental effort. ${ }^{8}$ Significant public resources must be made available before progress can occur.

\section{I}

\section{Smadi Business Administration}

\section{A. In General}

SBA's version of Come Play with Me involves loan programs as well as technical and managerial assistance. These programs have received special emphasis from the last two administrations. Under the Johnson Administration SBA embarked upon "Project OWN" which had as its goals "to insure free competition as the essence of American economic system of private enterprise, and to strengthen the overall economy of the Nation." The Nixon Administration renamed the program "Operation Business Mainstream" and announced that its goals were: $(x)$ to stimulate small business in deprived areas, (2) to promote minority enterprise opportunity, and (3) to promote small business contribution to economic growth and competitive environment. $^{10}$

Currently SBA offers small business financial and management assistance in the form of lease guarantees, ${ }^{11}$ management assistance, ${ }^{12}$ aid in obtaining government contracts, ${ }^{13}$ counseling services, ${ }^{14}$ and more than 800 publications covering successful practices in every small business field. SBA also expressly helps victims of disasters ${ }^{15}$

\footnotetext{
${ }^{8}$ Even with guarantees, private sources must charge the costs-namely red tape-of doing business with the government. Admittedly, direct loan programs involve a budgetary impact which guarantees avoid. Nevertheless, in the end, direct government loans are less expensive and should be less complicated.

- Small Business administration, SBA: What It Is, What It Does 2 (I970) [hereinafter referted to as SBA: What IT Is].

${ }^{10}$ Small Business Administration, SBA Business Loans 2 (1970) [hereinafter referted to as SBA BusinESS LOANS].

${ }^{11}$ SBA: What IT Is, supra note 9, at II.

12 Small Business administration, Management and Technical Assistance 2 (r968) [hereinafter referred to as Management and Technical Assistance]. Service Corps of Retired Executives (SCORE), Counseling at the Local Level (CALL), and Active Corps of Executives (ACE) are the best known management assistance programs provided by SBA.

${ }^{13}$ Small Business Administration, 8(a) Contracting 2 (I970) [hereinafter referred to as 8(a) Contracting].

14 SBA: What It Is 24; Management and Technical Assistance, at 2.

${ }^{15}$ SBA: What IT Is 8.
} 
and small business concerns which are displaced as a result of federally-aided contruction programs. ${ }^{16}$

The strength of SBA's role in Come Play with $\mathrm{Me}$ lies in its various loan programs. SBA can participate in, or guarantee, up to ninety per cent of a bank loan and, in certain instances, can make a direct government loan. ${ }^{17}$ Through the Economic Opportunity Loans (EOL) program, a loan of $\$ 25,000$ can be made to any resident in an area aided by $\mathrm{SBA}^{18}$ who does not have adequate income to support the basic needs of his family and has been denied adequate business financing through normal lending channels. ${ }^{19} \mathrm{SBA}$ may also help finance small firms through privatelyowned small business investment companies (SBIC's) by a loan or by a guarantee program..$^{20}$

The SBA programs look very attractive to a minority businessman and he can easily be persuaded to tackle the other games played by SBA. See if You Qualify is a crucial game. To qualify, a business must be a "small business"21 which, depending upon its categorization, ${ }^{22}$ has sales of $\$ \mathrm{r}$ million to $\$ 15$ million and 250 to $1,500 \mathrm{em}$ ployees.

Gotta Bring Your Own Ball is at the heart of all SBA programs. The applicant must meet general credit requirements which include the following:

(I) Have adequate capital prior to the loan, so that with an SBA loan he can operate on a sound financial basis; ${ }^{23}$

(2) Show that the past earnings record and future prospects of the firm indicate the ability to repay the loan and other fixed obligations out of profits. ${ }^{24}$

Specific percentages of required capital were dropped in 1970 in favor of the more vague standard of a "reasonable" amount of private equity. ${ }^{25}$ However, a reasonable amount of private equity is usually $\$$ I for every $\$ 9$ loaned for a local development company (LDC) $)^{26}$ and can be as much as $\$ \mathrm{I}$ for every $\$ 5$ loaned for other private businesses.

\footnotetext{
${ }^{10} \mathrm{Id}$. at 10.

${ }^{17} I d$. at 4 .

${ }^{18} I d$. at 5,6 . The area of coverage is the United States, Puerto Rico, and Guam.

${ }^{10} \mathrm{Id}$. at 6.

${ }^{20} I d$. at $15, x 6$.

${ }^{21}$ A "small business" is defined as "one which is independently owned and operated and which is not dominant in its field of operation." SBA Business LonNs, supra note ro, at 3. Gambling or speculative firms, newspapers, and television and radio stations are not eligible for SBA aid. SBA: WHAT IT Is, supra note 9 , at 2 .

${ }^{22}$ SBA: What IT Is, supra note 9, at 2.

${ }^{23}$ SBA Business LoANs, supra note ro, at 4 .

${ }^{26} I d$.

${ }^{25}$ This "reasonable" standard is applied to businesses owned by minority group members. SBA National Directive 5I0-IA at 49 (Jan. 9, I970) and app. 20, at 245 (Feb. 20, 1970).

${ }^{20}$ The extent of equity to be supplied by the LDC varies with the size of the town in which it is located. A community with a population exceeding ro,000 must contribute $20 \%$ of a project's cost in addition to the private equity investment so the leverage is not nearly as great as the 9 to $\mathrm{I}$ ratio implies. See, Sarali Business Administration, 502 Local Development Company Program 2 (ig68), for other LDC percentage involvement.
} 
SBA invoked Only One Game at a Time when it stipulated, by way of an unpublished directive, ${ }^{27}$ that government cash grants could not be used to furnish the required private share of the loans. Only One Game at a Time eliminates most uses for HUD, Model Cities, and EDA money in SBA games and, in conjunction with Gotta Bring Your Own Ball, has effectively prevented many minority businessmen from participating. This is true regardless of their personal ability, since eligibility is measured by an applicant's existing financial resources. However, capital is usually in short supply for development projects in inner city areas. ${ }^{28}$ The requirement, therefore, causes many applicants to be rejected without consideration of other factors which may balance the lack of personal funds.

Even though there is no set amount of capital necessary for any certain amount of loan, it is assumed that there must be "reasonable" personal capital invested. There is no evidence that regional SBA directors have used this flexible standard to make more money available to applicants. In fact, given SBA's past record, one can expect that even more rigid standards may now be applied than were required before the "reasonable" standard was promulgated.

SBA should adopt a policy which not only looks at the capital which persons organizing the business have available, but, in addition, considers the type of business and its chances for success in the field, the skill possessed in management and technical capacities of the applicants, the personal ambition and self-pride of the applicants, and the business contacts and other expected financing prospects available if the business becomes viable. Here, again, SBA must be willing to take risks.

SBA also requires Gotta Play with Those Guys by imposing the requirement that a minority businessman include a private lending institution as a participant. Most of these loans require bank participation, and direct government loans are made only in a small number of cases where private support is not available. ${ }^{29}$ Thus, SBA requires that:

(I) the bank and SBA participate together on a loan with a maximum SBA interest rate of $51 / 2 \%$ and maximum SBA participation not in excess of $\$ 150,000$ on any loan (the bank's interest rate is not to exceed $8 \%$ on the remaining amount of the loan) $;^{30}$ or

(2) the bank accept an SBA guarantee of $90 \%$ (or $\$ 350,000$, whichever is less) on a bank loan; interest is set by the bank..$^{31}$

These programs often require SBA to adopt the lending practices of the bank because it cannot function without bank cooperation. Even with a ninety per cent guarantee many banks are hesitant to participate in SBA's minority loan program

\footnotetext{
${ }^{27}$ SBA National Directive 535-2 at 42.

${ }^{28}$ Note, Community Development Corporations, 83 HaRv. L. Rev. 1558, I635-36 (I970).

${ }^{29}$ SBA: What Ir Is, supra note 9, at 3.

${ }^{30}$ Id. at 4 .

${ }^{31}$ Id. at 4 .
} 
because of the perceived high risk ${ }^{32}$ and red tape involved. In the participation program the bank is nearly as reluctant to loan money as it would be if it were the only source of the loan, for if a bank will not lend money to an applicant on its own, it usually is no more likely to do so even with SBA participation or backing. Gotta Play with Those Guys puts the program in the hands of the private lenders, who must agree to play with the minority businessman. Since such participation is difficult to come by, this game effectively eliminates many applicants. Thus, the minority businessmen who may need SBA most are excluded from the game, while others, who already qualify for private funding, are accepted and can receive more aid. This means SBA tends to help those businessmen who can help themselves, while denying help to those who really need government aid. This operating policy is in basic conflict with the philosophy Congress declared in creating SBA. ${ }^{33}$

The various versions of Rig the Game also seem very popular with SBA, and delaying tactics occur frequently in its early stages. Before SBA will make a loan on its own, the regional director must make a thorough investigation of the applicant's qualifications. Time and effort on the part of the applicant and the SBA staff in processing and completing a loan, however, is often excessive. It generally takes six to eight months from the time the applicant first expresses the desire for a loan and inquires about it to the time when the loan money is in his hand. ${ }^{34}$ Even prior loan recipients who later request more money run into delay problems. For an ongoing concern, or for someone who has expended his own money in expectation of going into business, these delays can be disastrous.

SBA attempted to curtail its use of the Time Delay tactic by recourse to a Simplified Blanket Loan Guarantee Plan (SBLG) ${ }^{35}$ Under this program, the bank participating with the SBA prepares a simplified set of forms which become the core of the report submitted to the regional director. This new program, however, only disguises the Time Delay, for SBA measures time in a very singular way under SBLG. Time does not start until SBA accepts an application; but the application is not "accepted" until all of the forms are in order, so that the final report can be written. On one SBLG loan traced through SBA, Time Delay was played as follows:

—December 29, 1969-SBA receives letter and forms already completed by SBLG bank.

-February II, 1970-Letter of December 29, rg69 marked "received, February Ir,

${ }^{32}$ Interview with Ray Willis, former Controller of Citizens Urban Opportunity Fund of Detroit, Michigan, in Detroit, Mar. I, I971.

83 ' $\mathrm{It}$ is the declared policy of the Congress that the Government should aid, counsel, assist, and protect, insofar as is possible, the interests of small-business concerns in order to preserve free competitive enterprise, to insure that a fair proportion of the total purchases and contracts or subcontracts for property and services for the Government . . . be placed with small-business enterprises ...." I5 U.S.C. $\$ 63 I$ (a) (1964).

${ }^{34}$ G. Britts, SBA Operation Mainstream: An Administrative Study 7, May 26, 1970 (unpublished paper delivered to the Seminar on Minority Economic Development, Harvard Law School).

${ }^{85}$ SBA National Directive 510-IA, Appendix 19, at 30 (Jan. 24, 1969); See also r3 C.F.R. $\$ \times 22.20$ (b) (1970). 
I970." A file was set up and the application was marked "accepted, February II, I970."

-March 18 , I970-Loan approved. ${ }^{36}$

SBA personnel play an important part in Rig the Game. The effectiveness of a lending program where profit is not the declared objective depends on the attitudes of the men involved and their willingness to get the job done. One man in the SBA network can adversely affect the progress of an application. A reluctant regional director could refuse many of the loans requested, and similar attributes in the assistant director for financial assistance could mean a drop in the number of loan recommendations made to the regional director.

Implementation of SBA programs varies greatly from city to city. According to a recent study, the effectiveness of some regional offices differed by a ratio of sixteen to one. ${ }^{37}$ Where the decisions emanate from a sensitized Minority Enterprise Team, ${ }^{38}$ the results have been much better. However, such a focus requires proper direction from the higher levels of SBA. Sensitive and effective employees all along

\footnotetext{
${ }^{30}$ Britts, supra note 34 , at 8 .

${ }^{37}$ Harris, Compensatory Capitalism: A Description and Evaluation of Project OWN, in Hearings on the Organization and Operation of the Small Business Administration Before the House Select Comm. on Small Business, 9Ist Cong., Ist Sess. $A_{32}-A_{35}$ (I969). The program submitted at fiscal year 1972 appropriations hearings showed the following data:
}

SBA LOAN APPROVALS*-MINORITY AND NONMINORITY

[In thousands of dollars]

\begin{tabular}{|c|c|c|c|c|c|c|}
\hline \multirow[b]{2}{*}{ Minority type } & \multicolumn{2}{|c|}{$\begin{array}{l}\text { Fiscal year } 197 x \\
\text { (March I97I) }\end{array}$} & \multicolumn{2}{|c|}{ Fiscal year 1970} & \multicolumn{2}{|c|}{ Fiscal Year 1969} \\
\hline & Number & Amount & Number & Amount & Number & Amount \\
\hline Black................ & 3,215 & $\$ 87,424$ & 4,083 & $\$ 107,639$ & 3,362 & $\$ 77,135$ \\
\hline Puerto Rican................ & 662 & $I 3,334$ & 846 & 16,925 & 610 & I0,I33 \\
\hline American Indian..$\ldots \ldots \ldots \ldots \ldots$ & 235 & $7,9 \times 2$ & 228 & $5,94^{8}$ & $9 \mathbf{I}$ & $2, I_{47}$ \\
\hline Spanish American............. & 1,033 & 23,018 & 871 & 19,239 & 461 & 9,953 \\
\hline Asian..$\ldots \ldots \ldots \ldots \ldots \ldots \ldots$ & 218 & I 1,532 & 205 & 10,102 & $\operatorname{Ir} 4$ & 4,852 \\
\hline Eskimos and Aleutian........... & 29 & 738 & 29 & 514 & 8 & Ir2 \\
\hline Subtotal................. & 5,392 & 143,958 & 6,262 & 160,367 & 4,646 & 104,332 \\
\hline Undetermined................ & & 948 & & 2,293 & Iro & 5,607 \\
\hline Other, including white......... & 9,124 & 588,404 & 8,798 & $546,95^{\circ}$ & 9,754 & 588,134 \\
\hline 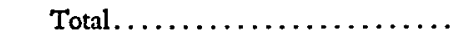 & 14,550 & 733,3 Io & 15,102 & 709,610 & $\mathrm{I}_{4,5} \mathrm{ro}$ & 698,073 \\
\hline
\end{tabular}

* Excludes disaster loans.

Hearings on Appropriations for the Dept's of State, Justice and Commerce, the Judiciary and Related Agencies for Fiscal Year 1972 Before a Subcomm. of the House Comm. on Appropriations, 92d Cong., Ist Sess., pt. IV, at 629 [hereinafter referred to as $S B A F Y \quad 1972$ House Appropriations Hearings].

${ }^{38}$ The function of a Minority Enterprise Team (MET) is to (a) coordinate SBA programs to stimulate minority owned business through expansion of existing businesses or creation of new businesses, (b) identify potential minority entrepreneurs, (c) assist minority businessmen with loan applications to banks, and (d) assist in providing managerial and technical assistance as necessary. The MET works principally in the ghetto and can therefore develop a close relationship with its businessmen. For a complete discussion of MET, see Hearings on the Organization and Operation of the Small Business Administration Before the House Select Committee on Small Bussiness, 9ist Cong., ist Sess., at AIo (I969). 
the chain of decision might serve to eliminate some of the large regional differences. A sufficient number of employees to handle the volume of work is also necessary. It is irrational to establish a program which is heralded as the cure-all for eliminating problems in business opportunity and then staff it so inadequately that it can not accomplish its goals without maximum inconvenience to its applicants. Yet unless SBA takes such actions, it will continue to Rig the Game.

\section{B. MESBIC Program}

SBA plays another variation of Rig the Game with minority businessmen who apply for assistance in setting up a minority enterprise small business investment company (MESBIC). In r 969 , SBA, in cooperation with the Department of Commerce, instituted the MESBIC program. MESBIC's were created by adopting the SBIC program, as authorized by the Small Business Act. ${ }^{30}$ Through MESBIC's, the express purpose of SBIC's, supplying venture capital and long term financing, was to be directed toward minority small business concerns. All SBIC's are authorized to purchase stock or debt securities issued by small businesses and thereby provide venture capital and financing. The MESBIC's have usually been created as subsidiaries of large corporations, which in turn provide the necessary private capital for the MESBIC's operations. Since MESBIC's are treated as separate entities for SBA loans and for income tax purposes, they are an attractive investment for large corporations.

The opportunity for minority ownership of MESBIC's has been limited. MESBIC's are subject to Gotta Bring Your Own Ball, and the minimum private investment required is $\$ 150,0000^{40}$ With $\$ 300,000$ of SBA assistance, the MESBIC can accumulate $\$ 450,000$ for investment. As large as this figure appears to be, it is far from adequate to establish a successful MESBIC. SBIC's which are capitalized for less than $\$$ m million have rarely been successful, and three to five million dollars is a more realistic figure for success. ${ }^{41}$ Since it is very difficult for a minority group to find financial backing of $\$ \mathrm{I}$ million to $\$ 2$ million size factors alone make the program inaccessible to minority businessmen and thus the game is "rigged."42 Moreover, any firm the MESBIC invests in must make a roo per cent to 500 per cent profit increase before the MESBIC benefits. ${ }^{43}$ This is too much to expect from the overwhelming number of businesses which ask MESBIC's for investment capital.

\footnotetext{
${ }^{39}$ I5 U.S.C. $\$ \$ 68 \mathrm{I}-87 \mathrm{~d}$ (1964). Relevant SBA regulations are contained in I3 C.F.R. $\$ \$$ ro7.I-I 4 II (I970).

${ }^{40} \mathrm{SBA}$ : What IT Is, supra note 9, at 15.

${ }^{41}$ Rosenbloom \& Shank, MESBIC Myopia: The Department of Commerce and Minority Economic Development, April 1970 (unpublished paper on file at the Center for Community Economic Development, Cambridge, Mass.). To encourage larger investments, SBA provides a three to one match for over \$r million in private investment.

22 The MESBIC program is not that attractive to large corporations either, since they must subsidize a significant portion of early expenses. This additional drain on corporate resources deters many corporations from becoming meaningful sources of venture capital. Thus, minority groups are not the only ones subjected to SBA "games."

${ }^{48}$ Interview with James Hill, President of PRIME (Pooled Resources In Minority Enterprise), a MESBIC, in Detroit, Feb. 15, x97r.
} 
Another SBA version of Rig the Game involves the requirement that investments by a MESBIC must be in a business owned or managed by at least fifty per cent minority personnel. ${ }^{44}$ Such a business has less chance for success than other businesses, because of the special problems faced by blacks and other minorities. ${ }^{45}$ All new businesses have limited chances for success, but the problems of an innercity business are compounded. Additional problems stem from the historical lack of business experience among minorities.

SBA guidelines further inhibit a minority role in MESBIC operations. MESBIC's are required to have two full-time managers on their staffs before a license will be granted. ${ }^{46}$ This requirement implies a permanent office and related expenses which can result in overhead of $\$ 35,000-\$ 60,000$ a year or more for even the smallest MESBIC. SBA further requires that such expenses be paid out of revenues, not invested capital. $^{47}$ It is absurd to believe that an investment company capitalized at from $\$ 450,000$ to $\$ I$ million, and with its funds committed to newly emerging minority businesses, can generate this kind of cash from early operations. Often the sponsoring parent organization must maintain the MESBIC staff on its own payroll and pay the overhead expenses. The success story of AIC (the MESBIC of Arcata) illustrates the fact that a benevolent parent is the only reason the MESBIC has prospered. ${ }^{48}$ In actuality a MESBIC can only operate as a subsidiary division of a strong, benevolent, and well-heeled parent and not as a separate business unit in any meaningful sense.

Another aspect of Rig the Game involves the size of the loans a MESBIC can make. Under SBA regulations a SBIC can not invest any more than twenty per cent of its capital in any single investment. Such a limitation may reduce the risk to the MESBIC from over-concentration, but it also eliminates ventures of significant scale and encourages only "Ma and $\mathrm{Pa}$ " tokenism. Moreover, because such businesses tend to be marginal, quantum change is inhibited. Ownership of such enterprises does little to give minorities any significant economic role, particularly if grocery stores and dry cleaning establishments are given preference over manufacturing firms and more extensive business which could employ many more times the number of people.

\footnotetext{
"SMall Business Administration, MESBIC, Minority Enterprise Smali Business Investment Company I (undated) [hereinafter referred to as MESBIC].

${ }^{4}$ Since so few minority businesses survive the SBA qualification games, it is not surprising that the SBA experience with minority businesses has been as good or better than with other types of businesses assisted by SBA. Interview with James Hill, supra note 43. The loss statistics, covering actual and estimated losses from March 1967 through fiscal year 1970, with respect to loans to blacks as contrasted with loans to whites reveal that for EOLS there were $9.88 \%$ losses on loans to blacks of $\$ 69$ million and $9.94 \%$ losses on loans to primarily whites of $\$ 4 \mathrm{I}$ million. For regular 7 (a) business loans there were $3 . x 6 \%$ losses on loans to blacks of $\$ 66$ million and $1.21 \%$ losses on loans to primarily whites of $\$ 972$ million. SBA FY 1972 House Appropriations Hearings 630.

${ }^{20}$ Rosenbloom \& Shank, supra note $4 \mathrm{I}$, at 5 .

${ }^{47}$ Id. But see, MESBIC, supra note 44, at 2. That publication states that although government funds or grants may not be used to capitalize a MESBIC, such grants may be used to cover operating expenses if this is not specifically prohibited by the terms of the grants.

${ }^{48}$ Rosenbloom \& Shank, supra note $4 \mathrm{I}$, at 3.
} 
If SBA is to succeed, it must be willing to take more risks with its loan funds. A sincere commitment to minority economic development will require that Congress accept the concept that such loans are inherently risky. SBA should thus be authorized to expend funds consistent with this philosophy. ${ }^{40}$ Only then, will SBA be willing to take chances and only then will existing self-protective SBA constraints be removed. As the program is now implemented, minority businessmen take all the risks in a game they cannot win.

As these game analogies indicate, a new and radically different approach must be taken by SBA if this program is to succeed. The present program seems to dictate that the profitable SBIC's will be of the least help to small businesses. The basic purposes of fostering minority enterprise will not be served unless the SBA program supports development of some large and efficient enterprises which can compete openly in the mainstream of American business. Some alteration of MESBIC size requirements and loan amounts must be made. Rules preventing initial operating expenditures to be paid from capital must be changed to allow the possibility of minority ownership of MESBIC's. Similarly, the ratio of SBA loan amount to private capital must be increased to permit minority ownership, despite their more limited capital sources. MESBIC's can benefit the minority community without "colonizing" such areas only where they are not dependent upon and not controlled by the same interests from which the community seeks to establish a degree of independence.

\section{Local Development Company Program}

SBA also has its games for the local development company (LDC) program..$^{50}$ Come Play with $\mathrm{Me}$ in this case involves attractive (nine to one) leveraging through LDC's for loans to finance small businesses. SBA can lend up to $\$ 35^{\circ}$,000 to each small business assisted by an LDC. ${ }^{51}$ The loans are intended to assist community development, as distinguished from solely individual entrepreneurs. ${ }^{52}$ The LDC must have a minimum of twenty-five stockholders, and the operations of the LDC must be limited to a specified area, with at least seventy-five per cent of its voting control held by persons living within the operations area..$^{53}$ The LDC can make loans to businesses affliated with or owned by the members of the LDC so long as none of the owners being assisted has more than twenty-five per cent voting control. The most effective use of an LDC is to employ it as part of the corporate shell for

\footnotetext{
$1{ }^{\circ}$ The SBA budget request for FY I97I was $\$ 320,500,000$. This figure represented an increase of $\$ 74,183,000$ over FY 1970 appropriations. Of this amount it was proposed that $\$ 10,000,000$ be used for the MESBIC program which is an increase of $\$ 5,000,000$ over FY 1970 use. Hearings on Appropriations for the Dept's of State, Justice, and Commerce, and the Judiciary and Related Agencies for Fiscal Year r97I Before a Subcomm. of the Honse Comm. on Appropriations, 9Ist Cong., 2nd Sess., pt. 4, at 802, 803 (1970) [hereinafter referred to as $S B A$ Hearings].

${ }_{\text {so }}{ }_{15}$ U.S.C. $\$ 696(1964)$; I3 C.F.R. $\$$ I08.502 (I970). There is also a state development company program, but it is relatively inactive. See 13 C.F.R. $\$$ Io8.50I (1970).

${ }^{61}$ SBA: What IT Is, supra note 9, at 7 .

${ }^{82} I d$.

${ }^{63}$ Id.
} 
a community development corporation (CDC) that carries on other economic development activities.

After interest is aroused, SBA's LDC program administration begins to play Rig the Game. The loans available from SBA have limited usefulness. Such loans apply primarily to the financing of plant construction, conversion, or expansion (including the acquisition of land). ${ }^{54}$ This financing cannot be employed to support the full range of activities necessary for development of a small business. Extensive controls by SBA are involved in each loan which an LDC makes. ${ }^{55}$ The applicant must be identified with a particular small business, and at both the time of approval and disbursement the LDC must show that the funds will be used by a small business.

The resultant Time Delay tactic complements SBA's playing of Rig the Game. The application and approval process for each loan can be long and tedious. Thus, the LDC will not have the flexibility to determine its own investment policy, and it will not have SBA funds available to take ready advantage of promising investments. The LDC acts solely as a loan packager, sponsor, and guarantor for SBA loans to a small business. In spite of the LDC's guarantee, SBA still scrutinizes each loan carefully and grants only those with very low risk of loss possibilities. The LDC seems to serve no meaningful purpose except as a "buffer" for SBA in locating loan applicants.

Rig the Game does not always lead to You Fail. However, such impediments often make the LDC program ineffective. Consequently, the best use for an LDC would be as a passive instrument, to be activated only when a section 502 loan is made. An LDC should not be perceived as an active corpus for community development.

\section{The Section 8(a) Program}

Come Play with $M e$, as applicable to section 8(a) of the Small Business Act of 1953, is the potential for SBA, as prime contractor, to enter into contracts with other federal agencies for supplies and services and to then subcontract the work out to small minority firms. ${ }^{5 \mathrm{e}} \mathrm{SBA}$ is able to negotiate the subcontracts under this program, and the lowest bidder does not necessarily receive the job. SBA, thus, can direct the work to a small business. Firms awarded these contracts are eligible to receive free management and technical aid in their operations.

The section 8(a) program looks promising, but its implementation leaves much to be desired. The minority businessman is forced to participate in Gotta Play with Those Guys, in this case with other government agencies which do not want to play with him or SBA would not have had to exercise its powers under section 8(a). This situation seems a clear invitation for failure.

\footnotetext{
${ }^{c t} I d$.

to The principal difference between a MESBIC and an LDC is that a MESBIC handles its own loans, whereas an LDC must get each loan individually approved by the SBA. Also, an LDC may fund fixed assets, whereas a MESBIC can fund fixed assets and operating capital.

${ }^{50} 8$ (a) Contracting, supra note 13 , at 2.
} 
The decision to enter into contracts with SBA is left to bargaining between SBA and the procurement officers of the respective government agencies. Therefore, the success of SBA under this program depends on the consent of another agency to apply its appropriations to this additional social purpose. If and when government contracts are granted, small businesses must tolerate low profit margins, rigorouslyapplied performance standards, legal complexities, vast amounts of paperwork, and other hazards typical of government involvement.

President Nixon's five-year plan to increase section 8(a) contracting may lead to more effective use of the program. ${ }^{\text {57 }}$ Until recently SBA had not extensively utilized section $8(a),{ }^{58}$ but if there is a sudden increase in section 8 (a) contracts, the agency will have to expand its staff in order to handle the new volume of business.

SBA also plays a version of Rig the Game with the section 8(a) program which includes the standard Time Delay tactic and the limited nature of assistance available through SBA. The section 8(a) program also has suffered from the lack of experience of SBA personnel in the contracts they must administer. Further, often it takes too long for a government agency to work through SBA, and consequently contracts of an immediate nature are sent elsewhere. Finally, although the picture is improving, another aspect of Rig the Game for this program is the fact that the contracts are seldom of sufficient size to make much difference to minority firms. ${ }^{\text {to }}$ Small contracts can be useful if there is sufficient volume, but this is unlikely to occur.

II

\section{Office of Economic Opportunity-Titue I-D}

\section{A. Special Impact Program}

OEO's version of Come Play with Me concerns title I-D of the Economic Opportunity Act of $1964,{ }^{60}$ which provided for the creation of Special Impact programs to address the critical problems of "dependency, chronic unemployment, and rising community tensions" within those urban areas having an especially large concentration of low-income persons, and within those rural areas having substantial outmigration from eligible urban areas. Each program receiving OEO funding had to

\footnotetext{
${ }^{67}$ See, $S B A$ Hearings, supra note 49 , at 803 . More emphasis will be placed on section $8(a)$ and more managerial and technical assistance will be provided to those minority businessmen receiving section 8 (a) contracts.

${ }^{58} I d$.

89 The March, I97I, summary of section 8(a) contract awards showed:

FY 1968
1969
1970
97 I to date
No. of Contracts 8 30 196 $35 \mathrm{I}$

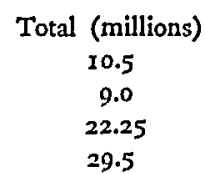

Excluding one $\$ 5$ million contract to Aerojet General, the average contracting was $\$ 70,000$. If one assumes a $7-8 \%$ profit margin, that means only $\$ 4900$ to $\$ 5600$ profit to the firm.

${ }_{42}^{10}$ U.S.C. $\$ \$ 2763-68$ (Supp. V, I970).
} 
be "of sufficient size and scope to have an appreciable impact on the [community]."."1 The OEO grants in fiscal year $\mathrm{I} g 6 \mathrm{~g}$ generally went to community development corporations (CDC's) and averaged about $\$$ million each. This represents ninety per cent of a project's cost, the remaining ten per cent being supplied by the private sector. ${ }^{62}$ Potentially these grants could have great flexibility and, if granted in large enough amounts, could have the impact intended.

The grant funds may be used for a variety of investment programs which will create jobs for poverty area residents, improve living conditions, develop managerial and entrepreneurial skills, and create opportunities for participation in ownership of production and commercial facilities by poverty area residents. Special Impact grants have also been made to venture capital pools. ${ }^{63}$

The Special Impact program has especially suffered from government game playing, particularly Change the Rules and Rig the Game. OEO has usually granted enough money for a minority group to begin operating but not nearly enough money for any group to become successful. Partly this was due to limited use of title I-D appropriations for community development corporations. In fiscal 1969, Congress alloted \$II million for OEO use; ${ }^{64}$ for fiscal I970, $\$ 30$ million was allocated out of $\$ 36$ million alloted. Of this, \$20 million went for urban CDC's, and of that, \$Io million went to just one, Bedford-Stuyvesant. ${ }^{65}$ Second, the average $\$ 1$ million grant given to each program is hardly enough to create a "substantial impact" in any large urban area. In fact, $\$ \mathrm{I}$ million is a small amount of capital with which to begin a SBIC or other community organization of any magnitude whatsoever. Although the ten per cent, Gotta Bring Your On Ball, private contribution requirement is not too stringent, only fifty applicants raised such private funds and went through the rigors of See if You Qualify in fiscal year I969. Only ten of these were accepted by OEO for funding. ${ }^{66}$ It is doubtful that organizers will be able to maintain the requisite funds every year to qualify for the program when the chances are only one in five that federal aid will be forthcoming. But spreading the wealth to other applicants, of course, would only assure shortfunding of the first recipients. ${ }^{67}$

\footnotetext{
${ }^{01} I d . \$ \$ 2763,2764$ (Supp. V, 1970).

${ }^{03}$ Federal grants to any program shall not exceed $90 \%$ of the cost of such program, including cost of administration, unless the director determines that assistance in excess of such percentage is required. I5 U.S.C. $\$ 2768$ (Supp. IV, I969). Thus the standard is flexible, and the $90 \%$ limit is not an absolute barrier to qualified persons who cannot acquire the necessary capital.

${ }^{88}$ Office of Economic Opportunity, Guidelines for OEO Special Impact Program Fiscal Year r969, at 5 (undated mimeo. on file at the Harvard Law Review) [hereinafter referred to as OEO Guidelines].

os See Hearings on Appropriations for the Dept's of Labor and Health, Education, and Welfare, and Related Agencies for Fiscal Year 1970 Before a Subcomm. of the House Comm. on Appropriations, 9xst Cong., 2d Sess., pt. 8, at 336,338 ( 1969 ) [hereinafter referred to as $O E O$ Hearings]. $\$ 8.3$ million went to 8 urban CDC's and $\$ 2.5$ million to 7 rural CDC's. Letter to author from Joseph Halbach, Director, Economic Development Division, Office of Program Development, OEO, July 20, 1971.

${ }^{65}$ Halbach letter, stipra note $6_{4}$.

${ }^{\circ O}$ OEO Guidelines, supra note 63 , at 5 .

${ }^{67}$ Of the $\$ 30$ million in fiscal year r970 only 5 of the 8 urban CDC's first funded were funded again; In fiscal year $197 \mathrm{I}, 7$ of the first $8 \mathrm{CDC}$ 's were funded again; 4 of those funded for the first time in fiscal year 1970 were dropped and one new one added. Halbach letter, supra note 64 .
} 


\section{B. Opportunities Funding Program}

If the player is successful in obtaining title I-D funds, Withdraw the Aid, another version of Rig the Game, begins. Programs which receive funds one year and are on the verge of becoming successful may offend local interests, and funds for future years may be curtailed. In order to make the "substantial impact" required under its legislation, however, title I-D funding should continue for a number of years. Failure to do so because of political pressures or "spread the wealth" philosophies make the original investment worthless. Moreover, such action reinforces minority perceptions of white hypocracy.

A further problem in the administration of the I-D grants involves the pervasive controls imposed on recipients by grant provisions. OEO still requires specific approval of each investment project. Technical assistance seems appropriate, but little capacity will be developed in the grantee if every investment decision is subject to prior approval.

The Nixon Administration has instituted a significant version of Change the Rules for title I-D funds. This has involved administrative change-over for a portion of these funds to a new program, Opportunity Funding. Opportunity Funding takes a different approach than Special Impact with respect to emphasis on particular communities. Using the Special Impact funds, Opportunity Funding does not concentrate on an "impact" area, but attempts to stimulate outside businesses to invest in the inner city. Opportunity Funding has three principle goals:

(x) to determine the loss factor when private credit and capital are engaged in low-income area projects and to identify those situations where losses can be kept within tolerable limits;

(2) to determine whether the use of proven guarantee, banking, and incentive arrangements will substantially increase the flow of private capital and credit into low income communities;

(3) to determine whether the information resulting from these pilot projects furnishes a basis for legislation to help achieve economic growth in low income communities. ${ }^{68}$

It was OEO's opinion that these goals could be met with a resulting rise in the strength of the commercial banking and savings vehicles currently present in target communities. $^{69}$

An Opportunity Funding corporation is composed of three units, an opportunity guarantee component, which considers capital and credit problems, a community development component, which handles the marketing of inner-city business securi-

\footnotetext{
${ }^{68}$ Office of Economic Opportunity, Opportunity Funding, An Economic Development Demonstration Program I (1970) [hereinafter referred to as OEO Opportunity Funding].

${ }^{80}$ Id. at 2.
} 
ties, and an incentive simulator component, which attempts to encourage private business investment in low income communities. ${ }^{\mathbf{7 0}}$

While the goals of the Opportunity Funding program cannot be questioned, there are grave questions about the means by which they are to be attained. The legality of the program is questionable, since it uses title I-D funds, which were designed to be used exclusively in selective poverty areas. ${ }^{71}$ Opportunity Funding attempts to diffuse the funds into a large number of areas, a policy which frustrates the title I-D concentration policy. The program also has selected only one isolated element, capital flow, out of all the poverty area problems, while title I-D was explicitly conceived as a multipurpose, coordinated attack upon many levels of problems. The Opportunity Funding program uses funds for a research and demonstration program which seems contrary to the goal of "arresting tendencies toward dependency, chronic unemployment, and rising community tension" of title I-D. ${ }^{\mathbf{2}}$ Such administrative shifts leave little or no opportunity for the countergame of Legal Review, since former title I-D recipients may have questionable standing to sue and strong disincentives to challenging their funding source. Switching to Opportunity Funding, moreover, intensifies Rig the Game because it reduces the limited title I-D funds available to community development corporations.

Opportunity Funding forces the minority businessman into Gotta Play unith Those Guys. To get assistance, he must go to the beneficiaries of Opportunity Funding, the banks, insurance companies, and other financial sources. Without more leverage or more desirable benefits available to these institutions, their aid will still contain the same restraints on low income investments that it did prior to OEO influence. OEO funds would be put to better use if Opportunity Funding concentrated more on making ghetto businesses better credit risks than on attempting to influence more lending institutions to lend money to risky, unstable ghetto businesses. Change the Rules also applies here since another level of bureaucracy has been added under Opportunity Funding. Special Impact funds are handled directly by OEO, but Opportunity Funding grants must go through OEO and then Opportunity Funding's component administrator. ${ }^{73}$ This needless duplication swallows up more of the title I-D allocation in administrative expenses.

The Special Impact funding of CDC's has come to be recognized as the most fruitful program yet tried in a low-income community. ${ }^{74}$ Opportunity Funding,

\footnotetext{
${ }^{70} I d$. at 5,6 .

${ }^{73} 5$ U.S.C. $\$ 552$ ( 1967 ). In fiscal year $1970, \$ 3.9$ million was diverted from title I-D funds for the use of the opportunity funding program; less was diverted in fiscal year 197x. Halbach letter, supra note 64.

${ }^{72}$ Id. A technical analysis of the insecure legal status of the Opportunity Funding Program is presented in a memorandum from Bert Griffin and David Madway to Donald Rumsfeld, OEO Director, April 2, 1970.

${ }^{73}$ OEO OPPORTUNITY Funding, supra note 68 , at 3.

"For example, the Special Impact funding of the Bedford-Stuyvesant Section of Brooklyn has been widely heralded; see Highlight Memorandum, Special Impact Program (Title I-D) Grant No. CG-8532, Aro. Specific accomplishments include a job creation program, community home improvement program,
} 
however, proposes to use its funds for purposes at odds with or unrelated to such a community participation approach. Lacking OEO funding, CDC's will not be able to continue to build a community participation model for economic development.

Moreover, Opportunity Funding continues a form of Rig the Game by the very nature of its emphasis on loan programs. In simple terms, Opportunity Funding is directed toward supplying the minority businessman with debt capital. It is debt financing, however, that usually overloads a business and restricts its growth. The critical difference here is that Special Impact can provide desperately-needed equity capital without burdening minority businesses with the less attractive debt funding.

\section{III}

\section{Economic Development Administration}

The Economic Development Administration (EDA) was created in 1965 as an agency of the Department of Commerce by an act which authorized a wide range of programs to help distressed communities attract new industry and permanent jobs. ${ }^{75}$ These programs include grants and loans for development facilities, industrial and commercial loans, and technical planning and research assistance.

EDA plays an intricate form of See if You Qualify. Relying on data supplied by the Department of Labor, the Department of the Interior, and the Department of Commerce, it designates areas which may be considered for aid. Each designated area then must prepare an overall economic development program (OEDP) within six months after it has received notice of its designation. ${ }^{78}$ If an area fails to submit an OEDP, it will become ineligible for consideration by EDA for two years. ${ }^{77}$ If the OEDP is approved by EDA, the area will be officially designated as a "redevelopment" area and EDA will state which types of assistance are available to the area. Each specific project in an area is examined, and aid is given only to those projects which meet other EDA standards. ${ }^{78}$

Urban areas may qualify as "redevelopment" areas in four ways: ${ }^{70}$

(I) as areas of "substantial and persistent unemployment";

(2) as areas with "low median family income";

(3) as areas which have lost a major employer producing added unemployment;

(4) as areas designated Special Impact areas. ${ }^{80}$

community facility development, manpower development, and housing development. See also Economic Opportunity Hearings, supra note I.

${ }^{75}$ Public Works and Economic Development Act of 1965, 42 U.S.C. $\$ \$ 3121-3226$ (Supp. V, 1970).

${ }^{70}$ O'Connell, Financial Assistance Available from the Economic Development Administration, in 6 LAw NoTES I6 (1969).

${ }^{77} I d$.

${ }^{78}$ These standards vary depending on the type of proposed project. Usually the amount of investment money available for the project plays an important role in its consideration. Note, supra note 28 , at I648. See also O'Connell, supra note 76 , at 18 , for an example of project requirements.

${ }^{79} 42$ U.S.C. $\$ 3 \mathrm{I} 6 \mathrm{I}(\mathrm{a})$ (I966).

${ }^{80}$ For a discussion of the limited nature of this qualification, see p. 80 stpra. 
The minimum "area" size under the Act is either an entire city, county, or metropolitan area. ${ }^{81}$ See if You Qualify has effectively eliminated almost the entire country. For most areas, the statistics do not accurately describe conditions in smaller portions within their boundaries. Therefore, the high unemployment and low family income of the ghettos are often hidden for purposes of EDA. Very few areas have been designated Special Impact localities under OEO, so this qualification does little to aid the expansion of EDA programs. Qualifications ( $\mathrm{r}$ )-(3) are so severe and rigorous that only three major cities had by 1969 qualified under $(x)$ and $(2),{ }^{82}$ and sections of only three cities had qualified under $(3) .^{83}$

EDA's approach to economic development consists primarily of attracting strong businesses to locate in economically depressed areas. ${ }^{84}$ As a result, minority businessmen are forced into Gotta Play with Those Guys. Large, established corporations and business are the associates a minority businessman must take. Another form of Gotta Play with Those Guys results from another EDA regulation, which provides that before any aid is given, both state and local government agencies for economic development must approve of the project. The applicant has no right to attempt to reverse state and local objections at the federal level. ${ }^{85}$ This requirement gives state and local agencies considerable power over organizations interested in EDA aid.

EDA also plays a very rigorous game of No Mistakes Allowed. In its evaluation of the eligibility for assistance of a low-profit, marginal business, EDA places emphasis upon demonstrated and exceptional management competence. ${ }^{86}$ EDA also permits little leeway in project design and retains tight supervisory control over all of its funds. Even minor programmatic changes must be approved, and no room is left for the use of discretion by project officials. ${ }^{87}$

EDA assistance comes with even tighter controls than financial aid from traditional sources. It definitely is not a program which will promote economic activity of any magnitude for minority firms. The number of areas qualifying for aid and the amounts available for distribution are too small. Everything EDA proposes to do can be done by other government agencies and private lending institutions with

${ }^{82} 42$ U.S.C. $\$ 3 I 5 I(b)(4)$. Some exceptions have been made for labor market areas which are portions of cities. See note 83 infra.

${ }^{82}$ The cities are Newark, Oakland, and Cleveland. U.S. Dept. of Commerce News Release, EDA 69-290 at 3 (June 29, 1969).

${ }^{83}$ These were Brooklyn's Navy Yard area, and the Chicago and Omaha stockyard districts. U.S. Dept. of Commerce News Release, supra note 82, at 3 .

84 "Our objective is to assist such areas to achieve stable and independent job-creating economics by encouraging private businessmen to establish or expand facilities there." Hearings on Appropriations for the Dept's of State, Justice, and Commerce, the Judiciary, and Related Agencies for Fiscal Year r97o Before a Subcomm. of the House Comm. on Appropriations, 9 Ist Cong., 2nd Sess., pt. 3, at 61, Testimony of Asst. Secretary Robert Podesta [hereinafter referred to as EDA Hearings]. See also U.S. DEP'T. OF Commerce, EDA Handiook 32 (I968).

${ }^{85} 42$ U.S.C. $\$ 3 I_{42}$ (b)(2), (Io) (Supp. IV, I969); EDA HaNdBook, supra note 84, at 36,37 .

${ }^{80}$ EDA HANDBOoR, supra note 84 , at 35 .

${ }^{87}$ Note, supra note 28 , at 1645 . 
fewer restraints and less red tape. Although EDA has significant funds, ${ }^{88}$ their use is so restricted as to be of little value for minority economic development. ${ }^{80}$

\section{IV}

\section{Department of Housing and Urban Developarent}

\section{A. Model Cities}

The Model Cities program was intended to provide "additional financial and technical assistance" above that available from existing federal grant-in-aid programs. ${ }^{90}$ It has a broad mandate in slum areas to expand housing, jobs, and income opportunities; to reduce dependence upon welfare payments; to improve educational facilities and programs; to combat disease and ill health; to reduce the incidence of crime and delinquency; to enhance recreational and cultural opporrunities; to establish better access between homes and jobs; and generally to improve the quality of life. ${ }^{91}$

Model Cities funds come from and are controlled by the Department of Housing and Urban Development (HUD). The program has wide-sweeping potential application in the field of urban economic development. Funds are supposed to be responsive to local determination and use. ${ }^{92}$ There is an elaborate planning process built into the program. ${ }^{93}$ Unfortunately, despite efforts to reduce federal control of local decisions, ${ }^{94}$ the Model Cities program maintains extensive review procedures and close federal supervision of projects. When contemplating a new major federal program, one can hope its administrators would learn from previous mistakes made by government agencies and eliminate some of the games in the administration of the new program. But the contrary is more apt to be true: the Model Cities program displays its own version of most of the games which have previously been discussed.

One hundred and fifty cities were chosen to receive Model Cities grants. ${ }^{95}$ In each selected city, a Model Cities area or neighborhood was outlined, and a city demonstration agency (CDA) was designated by the local government to concen-

\footnotetext{
${ }^{88}$ Appropriations for FY I970 reached $\$ 271,000,000$. Funding requested for FY 1971 is $\$ 263,000,000$. EDA Hearings, supra note 84 , at 58 .

${ }^{89}$ During calendar year 1969 , EDA made only 38 business loans which averaged about \$I million. Id. at 64,75 . Indications from the hearings are that this small number will drop cven lower in the coming years. Evidence of this decline is illustrated by the fact that requested funding for FY 1971 is down $\$ 8$ million from FY 1970 appropriations. See note 88 supra.

${ }^{80}$ Demonstration Cities and Metropolitan Development Act of 1966, 42 U.S.C. $\$ \$ 3301-13$ (Supp. IV, I969).

${ }^{91} 42$ U.S.C. $\$ 3303$ (a) (2) (Supp. IV, 1969).

${ }^{92}$ The Senate Committee report stresses that the "character and content of the program must be based on local judgment as to the cities' needs"; S. ReP. No. I,439, 89th Cong., 2d Sess. I4 (1966).

${ }^{03}$ See 42 U.S.C. $\$ 3304$ (Supp. V, I970).

${ }^{84} \mathrm{See} 42$ U.S.C. $\$ 3303$ (b)(I) (Supp. V, I970).

${ }^{\mathrm{os}}$ Hearings on the Progress of the Model Cities Program Before the Subcomm. on Housing and Urban Affairs of the Senate Comm. on Banking and Currency, 9Ist Cong., Ist Sess. 13 (1969).
} 
trate and coordinate federal, state, and local public and private programs within the area. ${ }^{90}$ See if You Qualify is played indirectly through restrictions imposed on the CDA, which in turn is to apply the rules to those requesting the CDA funds. Thus, recent HUD regulations indicate that to obtain Model Cities money one must play certain qualifying games. ${ }^{97}$ One is a form of Gotta Play with Those Guys, where minority businessmen come under regulations which require that, normally, Model Cities funds be used in conjunction with private capital. ${ }^{98}$ Consequently, Model Cities funds should not be used to provide loans to business enterprises in the absence of participation by other lenders or guarantors. ${ }^{99}$ Since the local administering agency (CDA) and the local governing body (city council) must approve all projects funded by Model Cities, Gotta Play with Those Guys forces recipients to play with local government as well as private "partners." In a positive sense Model Cities attempts to prevent Only One Game at a Time. Use of funds from SBA, OEO, and EDA is encouraged. ${ }^{100}$ The logic of Model Cities cannot be faulted, for government agencies must begin to coordinate their efforts. But, commendable as the idea is, Model Cities money cannot be used with that of the other federal program if other federal agencies will not cooperate.

Although HUD professes that major program decisions lie with local governments, ${ }^{101}$ the Department has engaged in a spirited version of Change the Rules which severely restricts local initiative. It is often difficult for minority enterprises to determine what rules are in effect. For example, the recent HUD regulations on economic development only became "official" in November, I970, while informal rules had been applied since July, I969. ${ }^{102}$ Previously, the area of economic development had been left to local discretion, aside from general HUD review of projects and local programs. ${ }^{103}$ Administrators at HUD, nevertheless, did not hesitate to Change the Rules applicable to this program area when they desired.

${ }^{80}$ This was in accordance with the provisions set out in 42 U.S.C. $\$ 3301$ (Supp. V, r970). The CDA was to work in conjunction with a citizen participation component, generally one elected by residents of the model neighborhood.

${ }_{07}$ The most recent HUD regulations were stated in HUD, CDA Letter Ioc Transmittal Notice MC 3135.I Supp. 2 (Nov. I970) [hereinafter referred to as CDA Letter Ioc].

${ }^{\circ}$ Id. at 3. It suggested that Model Cities funds not be used on a grant basis. Alhough these guidelines became official in November, I970, the discussion of the Citizens Urban Opportunity Fund Program below will illustrate that these more stringent guidelines were in fact frequently used prior to that date.

00 "Every effort shall be made to obtain the participation of private lenders in financing businesses." Id. ${ }^{100} \mathrm{Id}$.

101 "The purpose of the Model Cities Program is to achieve, through the carrying out of plans developed by local governments and their citizens, substantial improvement in the quality of life of people living in blighted city neighborhoods." CDA Letter No. I, at I, Oct. 30, Ig67. "Cities are encouraged to experiment with new program approaches. Each city should determine its own program emphasis. . .." Id. at 2.

${ }^{102}$ See North City Area-Wide Council, Inc. v. Romney, 428 F.2d 754, 757 (3d Cir. I970).

${ }^{103}$ The Secretary must determine under section $\mathrm{IO}_{3}(\mathrm{a})$ of the Act [42 U.S.C. $\$ 3303$ (a)] that the program submitted by the city is eligible for funding pursuant to the criteria set forth in that section. Section 105(a) [42 U.S.C. $\$ 3305$ (a) states: "The Secretary is authorized to approve comprehensive city demonstration programs if, after review of the plans, he determines that such plans satisfy the criteria ...." 


\section{B. Model Cities Case Studies}

\section{Philadelphia}

HUD's imposition of Gotta Play with Those Guys and Change the Rules is illustrated by a recent case involving the Model Cities program in Philadelphia. In March, I96\%, the city of Philadelphia applied for a planning grant from HUD for its model neighborhood in North Philadelphia. The citizen participation component of the program, the North City Area-Wide Council (AWC), was organized and funded. Gotta Play wth Those Guys involved the city with AWC, and they jointly proceeded during the ensuing year to plan for the execution phase of the program. At the end of the planning period, on December 3I, I968, a comprehensive plan for the first year of execution of the program was submitted to HUD. The plan required $\$ 49$ million, although only $\$ 25$ million had been allocated by HUD for the Philadelphia program. ${ }^{104}$ During negotiations with the city's representatives, in addition to suggesting the necessity to revise the request to fall within the targeted amount, HUD raised "concerns" because AWC, the operator of many projects in the plan, was also to evaluate its own effectiveness. HUD questioned the impartiality of: evaluation under such circumstances.

A revision of the plan by the city in cooperation with AWC was made by way of a supplement sent to HUD on April 30, 1969. The supplement proposed a wide range of programs to benefit the model neighborhood which were to be implemented by the city agencies or existing private entities. The new plan also proposed that a large portion of the program be carried out by seven new nonprofit corporations, acting under contract with the city, with specific responsibilities for housing, land use, health, education, and (significant here) economic development. To enhance the citizen involvement in the corporations, a majority of the directors of four of the corporations and significant minorities for the other three were to be selected by the citizens of the model neighborhood through the AWC.

In May, I969, HUD expressed reservations about the plan as now "supplemented" and reiterated its concern over AWC's dual involvement in the direction of the corporations and evaluation of the program. In response to the HUD objections, the city submitted a further supplementary statement to HUD on June 9, I969, without the participation or approval of AWC or other residents of the model neighborhood. In that statement, the city agreed that only one-third of the directors of any corporation could be appointed by $\mathrm{AWC}$, the remaining members to be appointed by organizations selected by the city with the "consultation" of AWC. The final decision was to remain with the city. The city also reserved the right to appoint such additional government representatives as directors as the city deemed appropriate.

Even this supplementary plan was apparently not sufficient for HUD, which on July 3, 1969, found the city's latest proposal "acceptable" only if (I) citizens were

\footnotetext{
${ }^{104}$ Brief for Plaintiff at 2, North City Area-Wide Council, Inc. v. Romney, Civil No. 69 Ig09 (E.D. Pa., Nov. ro, rg69).
} 
forbidden to nominate as a director a member of AWC and, (2) after the first year, board members were selected by some method other than nomination by AWC. ${ }^{105}$ To emphasize its desire to control these matters, HUD only approved $\$ 3$ million of the $\$ 25$ million, thus providing funds solely for administration activities pending resolution of the dispute. Although the city offered to continue to contract with AWC as the citizen participation component for the program, including $\$ 4 \mathrm{I}, 000$ for AWC's monthly operating budget, AWC tried to fight HUD's tactic of Change the Rules and instituted the countergame, Legal Review. AWC's suit charged that HUD had violated its own published regulations and its statute since the Act required "widespread citizen participation" and an "emphasizing of local initiative in the planning, development and implementation" of the program. ${ }^{106}$ AWC also asked that its funding be continued and that the city be enjoined from using HUD funds to aid any other citizen organization during the pending litigation.

The federal district court held that the Council lacked standing to maintain a legal action and that even if requisite standing existed, neither HUD nor the city had violated the regulations. On appeal the key issues before the Third Circuit were: (I) Did AWC have adequate standing to sue? (2) Were HUD's actions a legitimate exercise of departmental discretion and thereby not subject to judicial review? and (3) Were the restraints imposed upon AWC consistent with statutory emphasis and other legal precedent?

In a brief opinion ${ }^{107}$ the court of appeals reversed the district court, holding that (I) AWC had standing to sue by virtue of the decisions in Association of Data Processing Service Organization, Inc.v. Camp..$^{108}$ and Barlow v. Collins; ${ }^{109}$ (2) " $[\mathrm{u}] \mathrm{n}-$ less the language or structure of a particular statute precludes judicial review, there is a presumption that administrative action is reviewable", ${ }^{110}$ (3) the implementation of the statute requires the constructive involvement of citizens in the model neighborhood area; and (4) the city government is responsible for seeing that the citizens are fully involved in policy making, planning, and execution of all program elements. ${ }^{111}$ In this case neither the requirements added on June 9 , 1969 , nor the requirements added on July $3, x 969$, involved any citizen participation. ${ }^{112}$ The court acknowledged that a veto power in the neighborhood citizens is not necessary, as was "full citizen participation" not required for minor decisions. For major decisions which may influence the basic strategy of the program, however, consultation with

\footnotetext{
${ }^{105}$ North City Area-Wide Council, Inc. v. Romney, 482 F.2d 754, 757 (3rd Cir. 1970).

${ }^{100} 42$ U.S.C. $\$ 3303$ (b)(I) (Supp. V, I970).

${ }^{107} 428$ F.2d at 754 .

${ }^{208} 397$ U.S. 150 (1970).

100397 U.S. I59 (1970).

${ }^{210} 428$ F.2d at 757. The court also noted: "Moreover, the issue here does not concern, as claimed by the Government, 'agency action ... committed to agency discretion by law.' (5 U.S.C. $\$ 70 I(a)(2)$ ). Instead, it concerns the question whether the administrative agency has conformed with the statutory requirements, and this question is a proper subject for judicial review." Id.

${ }^{211} I d$. at 758 .

${ }^{112}$ Id.
} 
the citizens' group is, in the court's view, essential. Thus, the court found the unilateral actions by the city and HUD involving major modification of the program a violation of the Act. The case was remanded to the district court and hearings were held. The district court has subsequently ruled that despite the circuit court opinion, AWC would not be reinstated and the revisions would stand.113

From this case one may fairly question the advisability of fighting "city hall" by recourse to the countergame of Legal Review. AWC has been without funds since July, 1969, and the corporations have not been active or effective in the areas originally planned for them. ${ }^{114}$ The lesson here may be that the minority businessman must acquiesce to the government's often changing rules if he expects any federal aid to be given. Particularly frustrating to AWC, however, was that once having adjusted to a particular set of rules, and having been successful in playing by them, the AWC found that its success in self-determination was to be denied because of the federal, not the city, bureaucracy. City revisions were clearly the direct result of HUD's refusal to approve the program until supplementary changes were made. Under a reasonable reading of the statute, HUD had limited authority to request these changes. ${ }^{115}$ It had even less basis to make changes without regard to the procedural due process set forth in the Administrative Procedure Act which requires publication of new or revised regulations. ${ }^{116}$ The experience of AWC, however, illustrates that the courts may be rather limited vehicles for protecting the rights of groups who are attempting to work within the system. Only if the admin-

\footnotetext{
${ }^{113}$ Opinion and Order, No. 69-1909, July 9, r971. The district court seems to have failed to comprehend that there was a rule change by HUD, see note 138, infra; that the new rule should not be applied retroactively; and, that any changes in the city's program, even absent a change in rules, should have required consultation with the then citizen participation organization, AWC. Admittedly it was a difficult case since a finding for AWC on any of these points would require reinstating AWC and negotiations over program content. This would effectively stall the program for an additional period.

11\$ Telephone interview with Austin Norris, Director of Administration, Philadelphia Model Cities Agency, Apr. 28, I97x. Of the seven proposed nonprofit corporations, only two have been organized: the Urban Education Institute and the Economic Development Corporation. The former is operative, but the latter has still to appoint its directors. The principal corporation is a section 501 (c)(3), Model Cities Community Foundation. There are two related corporations in the economic development complex for the program, each with contractual relationships with the Foundation. One is the Model Citics Economic Development Corporation, which as a stock issuing corporation will be an operating arm of the Foundation. The other is an Urban Venture Capital Corporation, which is profit-making. One-half of its 200,000 shares will be purchased by the Foundation and the remainder sold to model neighborhood residents, thereby providing paid-in capital in addition to the $\$ 7$ million to be made available to the Venture Capital Corporation for investment in inner-city businesses.

As a result of the law suit, Philadelphia delayed reorganization of a citizen participation component until the initial successful result in the district court. HUD funds during the interim were also limited. Sixteen local councils were organized. There was also a central body called a "Continuation Committee." At present, a 47-man Citizens Advisory Committee provides the citizen participation component for the program. In addition to two representatives from each local council, there are 15 persons appointed from the phase-out Continuation Committee. The basis for appointments of directors to the economic development corporations are apparently substantially the same as set forth in the June gth supplementary statement to the city's Model Cities Program.

${ }_{115}$ See 42 U.S.C. $\$ 3303$ (b) (I) (Supp. V, I970).

${ }^{116} 5$ U.S.C. $\$ 552($ b) (I)-(3) (Supp. II, I967); See also 5 U.S.C. $\$ 553$ (Supp. II, I967); Skoler, Legal and Quasi-legal Considerations in New Federal Aid Programs, 56 GEo. L.J. X144, II55, \& n.40 (I968).
} 
istrators of these programs feel bound by essential elements of fairness in applying and living within their rules, as well as in the process of changing such rules, can a wholesale and possibly violent challenge to our existing government be averted. When some come to realize that the government is indeed "playing games" with them, the reaction may become extreme.

There may have been valid reasons to question the potential for economic development as envisioned by the newly-created and inexperienced corporations in the Philadelphia program. But, if they constituted the agreed-upon program of the city and AWC, once having raised these doubts, the federal bureaucracy was obligated (as the circuit court determined) to abide by local decisions. In fact, difficulties with federal control of local decisions have been one of the strong arguments for some form of federal revenue sharing or bloc grants to localities. ${ }^{117}$

\section{Detroit}

In Detroit the effect of Change the Rules along with No Mistakes Allowed has resulted in the demise of a promising and innovative program closely related to economic development activities in the city's Model Cities program. ${ }^{118}$ Detroit's program, Plans for Progress, called for the establishment of a Citizens Urban Opportunities Credit Bank which would provide grants, loans, and loan guarantees for various personal objectives. As set up in 1969 by contract with the city, the Citizens Urban Opportunity Fund (CUOF), as it was renamed, incorporated the concepts of "grants and loans to provide individual and community options and incentives toward self-improvement." The program was to function as a "gap-filling revenue." It was also to serve as the depository for funds to be distributed to other contractors and to handle the disbursement and accounting for such other funds. There was to be a ceiling upon grants, and variable interest was permitted on loans. In most cases recipients were given vouchers exchangeable for goods. CUOF then redeemed the vouchers from the merchant selected by the recipient. The Citizens Government Board (CGB), the citizen participation component in the Detroit program, had responsibility for the implementation of CUOF in "partnership" with the CDA.119 They were jointly to appoint a board of directors for CUOF, selecting both public and

112 "The major difficulty is that States and localities are not free to spend these funds on their own needs as they see them. The money is spent instead for things Washington wants and in the way Washington orders." Message form the President Relative to Revenue Sharing, Feb. 4, I97I, H.R. Doc. No. 92-44 at 4, 92nd Cong., rst Sess. (I971). AWC's problems with respect to economic development activities are not uncommon in the Model Cities program. In Fresno, California, one major difficulty was the attempt to overcome SBA's Only One Game At A Time rule, so as to use Model Cities funds to provide the initial capital to match SBA funds for SBIC. See Note, supra note 87 , at 1558 , $1606 \& \mathrm{n} .86$. SBA still seems to be adamant about refusing to allow flexible use of Model Cities funds along with SBA funded programs. See notes 27,44 supra.

${ }^{118}$ This program, Citizens Urban Opportunities Credit Bank (as it was first known), seemed to be one of the more innovative approaches taken by Model Cities in developing new financing techniques to overcome obstacles to full opportunities for development for both individuals and organizations. See Hetzel \& Pinsky, The Model Cities Program, 22 Vand. L. Rev. 727, 743 (xg69).

${ }^{110}$ Comprehenstve Demonstration Program, City of Detroit, Citizen's Urban Opportunity Credit Bank, Project Description 35i (ig68). 
private representatives for the sixteen positions. CUOF's proposed budget was for $\$$ I million plus administrative costs, and the Fund also was disbursement agent for almost $\$ 5$ million in additional program funds. ${ }^{120}$

Under the contract with the CDA, CUOF was to provide grants, loans, and loan guarantees "to any person or group, for any purpose, for any amount, and under any terms consistent with the provisions of this Agreement."121 The CGB was to select four directors, one from residents in each model neighborhood sub-area, and one from each of five additional CGB standing committees that would be concerned' with CUOF's operations. The other seven directors were to be appointed by existing organizations, both private and public, including a faculty member from a local law school, a member of a commercial bank, and one from the staff of the model neighborhood agency. Limits were set on grants and loans to individuals (\$1500) and groups $(\$ 15,000)$, unless higher amounts were approved by a two-thirds vote of the directors. The contract was finally approved on February 3, I970, with certain standard HUD provisions attached. These included the requirement that "unearned payments under the contract could be suspended or terminated upon refusal to accept additional conditions that may be imposed by HUD at any time...."122 There were also provisions permitting the $\mathrm{CDA}$ to terminate for cause or, with proper notice, for convenience.

Rig the Game was also present there in the form of time delays. Seven months elapsed between the time the city approved the plan and receipt of the funds by the CDA. Another six months passed between receipt of the money by the CDA and the signing of the CUOF contract on February 3, I970. Following the contract approval in February, intense pressure was generated to get the project operational and to distribute the funds. ${ }^{123}$ Nationally, HUD was under criticism for the small amount of money which had actually been expended in the Model Cities program. The pressure resulted in an acceleration of CUOF's activities to get the money to the people that needed it. A foreseeable result of that process was the potential for minimal adherence to administrative procedures, and, as a result thereof, there was failure to conform to safeguards for the handling of money.

A new city administration took over in Detroit after the signing of the contract, and the necessary result was a change in CDA directors. ${ }^{124}$ CUOF had been required to take the CDA as a partner under the contract. ${ }^{125}$ Having adjusted to Gotta Play with Those Guys for one CDA staff, CUOF was required to readjust and accept

${ }^{121}$ Contract, City of Detroit Model Neighborhood Agency and CUOF, Inc., at I (b), Scope of Services r. (Feb. 3, 1970) [hereinafter referred to as CUOF Contract].

${ }^{122}$ Model Cities Administration, Supplementary General Conditions for Contracts with Operating Agencies and Contractor (Incorporated by reference into CUOF Contract, Part I, 6, 2), MCGR 3100.8 Appendix 6, page 2 (July I969).

${ }^{123}$ Detroit News, Sept 27, 1970, § B, at 6; Detroit Free Press, June 15, 1970, § A, at 3.

${ }^{124}$ With election of a new mayor, the resignation of the CDA Director was accepted. A new Director was appointed and took over about February, 1970.

${ }_{125}$ CUOF Contract, supra note $12 \mathrm{I}$, at $\mathrm{I}$.
} 
new personnel from its required partner. The necessary adjustment, as it turns out, was unsuccessful. The new director for the CDA imposed tight administrative control of the program. ${ }^{128}$ According to some reports, he evidenced concern over the operation of CUOF. ${ }^{127}$ Then came the same Change the Rules problem which AWC experienced in Philadelphia.

Although discussions apparently were initiated between the CDA and HUD as early as August, 1970, ${ }^{128}$ on September 21, 1970, a memorandum from HUD the Regional Office in Chicago enunciated certain conditions for continued requisitions of funds to CUOF. In brief HUD's concerns were:

"( $\mathrm{I}$ ) CUOF seemed to have been making only grants and needed to develop some ratio of grants to loans consistent with the understanding HUD thought it had with the CDA some eighteen months earlier;

(2) some grants had gone to members of the board of directors, which HUD implied created possible conflicts of interests;

(3) some of the grants seemed to be for purposes other than those for which CUOF had authority;

(4) adequate reports on the use of the funds had not been provided the CDA and HUD." 129

On the same day the CDA director set forth additional requirements in a letter to CUOF:

The membership of the Board of Directors must conform to a July 29, 1970 "statement of policy" which was "promulgated" by HUD which restricts CGB members from serving on the CUOF Board and reduces the number who may be appointed by the CGB to CUOF. ${ }^{130}$

At the same time, this letter affirmed a unlilateral CDA reduction of $\$ 750,000$ in the grant amount to CUOF, purportedly made in August, I970.

From the above commentary by HUD and the CDA (and it is not clear whether the federal response was at the request of the CDA or vice-versa) both seemed to have imposed, along with appropriate requests for a firming-up of CUOF procedures, new requirements which had not been agreed to by CUOF. As in the situation faced by AWC, basic changes in the board of directors of CUOF were to be required without any federal issuance of formal regulations. Moreover, these requirements were clearly contrary to the specific provisions of the CUOF contract with the CDA. ${ }^{131}$ After attempts at negotiation, including a proposed agreement of

\footnotetext{
${ }^{126}$ See sources cited in note 123 supra.

${ }^{127}$ Id.

${ }^{128} \mathrm{Id}$.

${ }^{220}$ Memorandum from Alan Goldfarb, Regional Administrator to Sylvester Angel, Jr., CDA Director, Sept. 2I, 1970.

${ }^{130}$ Letter from Sylvester Angel, Jr. to Ralph Richardson, Sept. 2r, I970. It should be noted that the only policy statement "promulgated" by HUD was CDA Letter Ioc, which was not issued until November, x970.

${ }^{132}$ CUOF Contract, supra note I2I.
} 
understanding which seemed to resolve almost every issue, ${ }^{132}$ CUOF went to court to prevent the CDA cut-off of funds. ${ }^{133}$ Disbursements were halted both by the CDA and temporarily by the court. Attempts were then made by the CDA to go through CUOF's transactions, and CUOF acceded to these requests. Based upon a superficial examination of the books and review of some transactions, the CDA went before the City Council to ask termination of the contract with CUOF. ${ }^{134}$ The CDA director, however, failed to present any evidence of impropriety before the Council, and it refused to terminate the contract. ${ }^{\mathbf{1 3 5}}$ The investigation by the city of CUOF's books and records, nevertheless, continued. The CDA again went before the Council with some tentative audit findings. After heated debate and a threat by HUD to cut off all Model Cities funds to Detroit, the Council voted five to four to terminate the contract. ${ }^{136}$

It should be noted that by the time that the September HUD memorandum came, CUOF had been operating only six months under contract and had been actually issuing funds for only two of those months. Thus, the CDA and HUD pressure were illustrative of the game No Mistakes Allowed. It is difficult to see why the CDA and HUD instead could not have halted funds for CUOF and required a revision of procedures sufficient to assure that funds were not used improperly. The agreement proposed by CUOF during negotiations on September 24, 1970, was sufficient to have assured this result. In that proposal CUOF offered to establish a policy for loan-grant ratios, although it had no knowledge of any agreement between HUD and the CDA in that regard. Second, pending resolution of the conflict of interest issue raised by HUD, CUOF offered to abide by the federal interpretation. With respect to the purposes for which loans or grants could be made, CUOF offered to review such criteria with the CDA and HUD, although it had thought that under its contract with the city the type of loans or grants were in its sole discretion. Finally, CUOF agreed to a review of certain grants it had made. It further agreed to limit for the present its expenditures of funds to one-half of the original amount set forth in the contract, $\$ 500,000$. The question of the composition of the board of directors was left to negotiation between the CGB and the CDA..$^{137}$

These offers seem reasonable and perhaps would have resolved many of the deficiencies which concerned HUD. From all of the circumstances, CUOF concluded that the issue of citizen control seemed central in the dispute. ${ }^{138}$ In part, that

\footnotetext{
${ }^{182}$ Agreement of Understanding Between CUOF and MNA, Sept. 24, 1970. See also Detroit News, supra note $\mathrm{x} 23$, at $6-\mathrm{B}$.

${ }^{188}$ CUOF v. City of Detroit, et al., Civ. No. $16_{5} 6_{7} 6$ (Cir. Ct. Wayne County, Mich., Sept. 22, 1970).

${ }^{184}$ Detroit News, supra note I23. This must have seemed to CUOF like bad faith since the ostensible purpose of the review was to determine what had occurred and what changes were needed, not to provide a basis to terminate the program.

${ }^{136}$ Detroit News, Oct. 5, I970, at I.

${ }^{188}$ Detroit Free Press, Oct. 30, 1970, at 2.

${ }^{137}$ Agrcement of Understanding, supra note 132. Over $\$ 330,000$ had been committed at that time.

${ }^{188}$ Detroit News, supra note 123. The CDA was seemingly only reflecting the change in policy of HUD. In an address on July 8, 1969, Robert Baida, the Deputy Assistant Secretary, Model Cities Administration, said: "Unfortunately, this administration inherited a philosophy in many areas of the country
} 
conclusion is reinforced by the recourse of HUD and CDA to the game No Mistakes Allowed. This game effectively prevented CUOF from making the necessary adjustments so that it could proceed in a more orderly fashion. Conceding that mistakes had been made, the failure by the CDA and HUD to permit reorganization seemed to CUOF to reflect the policy change toward limiting citizen participation in the Model Cities program which had been made in Washington with the change of administrations.

The difficulty was not the change in policy, so much as the way in which the change was handled. Admittedly, the initial HUD regulations were not necessarily a full recitation of HUD's authority to set the role of citizens and their control of operating agencies for Model Cities projects. Nevertheless, there was a failure to accord any consideration to outstanding contract commitments (of which HUD had notice) and an attempt at ex post facto imposition of the new policy. Moreover, this was done prior to issuance of the new regulations. This type of agency action was described in the article, The New Sovereign Immunity, ${ }^{139}$ where it was characterized as "sovereign lawlessness."140 That article also documents similar action taken by the government in one of the OEO programs. In that case also the game of No Mistakes Allowed was played to a similar conclusion for the recipient of the federal funds. ${ }^{141}$

The analogy to ex post facto imposition of new regulations seems appropriate here since it was not until November, I970, that HUD formally issued its regulations. Even then, they were not published in the Federal Register as is arguably required by the Administrative Procedure Act. ${ }^{142}$ Although the Model Cities program is relatively new and still developing, significant changes in policy should not be arbitrarily or informally imposed. This is the clear import of that part of the decision in North City Area-Wide Council v. Romney ${ }^{143}$ in which the court comments that the Secretary acted illegally in imposing additional significant terms of his own without citizen consultation. . $^{144}$

Where there are existing contracts setting forth the rights and obligations of the grantee city and sub-recipient CUOF, these provisions are subject to a yearly review and could be revised or terminated at that time. The contract should not be abrogated at the whim of the administering federal agency. This is not to say, however, that changes in policy and procedures should not be made-especially where they may reflect additional wisdom in administering complex and novel programs. What it does imply is that due process must be followed in making such changes. In

dedicated toward extensive citizen control. Because of this, many first and second round cities are in difficulty with their programs, and in some cases we have found it necessary to require substantial revisions prior to the tender of planning or execution contracts."

${ }^{182}$ Cahn \& Cahn, The New Sovereign Immunity, 8I Harv. L. Rev. 929 (I968).

${ }^{160} I d$. at 930 .

241 Id. at 930-34.

${ }^{143}$ See note II 4 supra. The concept of due process of law would seem to require no less.

${ }_{123} 428$ F.2d 754 (3d Cir. 9970 ).

14 Id. at 758 . 
addition, in keeping with the innovative spirit of the program, the operators of projects should be counseled concerning their decisions, but allowed to make their own mistakes. It is totally unrealistic to expect either perfection or immediate success from newly developing corporations. Given the lack of effectiveness of most existing efforts, new institutions responsive to self-determination needs are required, and it is certainly not clear that all wisdom lies in Washington concerning the development of local projects.

A final word should be uttered concerning the November, 1970, regulations. They clearly involve the imposition of some of the games similar to those played by other federal funding agencies. For instance, they require that grants not be used to finance a business ${ }^{145}$ (Gotta Bring Your Own Ball); that there normally be participation by private lenders or guarantors before HUD funds are loaned ${ }^{148}$ (Gotta Play with Those Guys); and that for new corporations no more than one-third of the directors be selected by the citizen participation component ${ }^{147}$ (Change the Rules). Other regulations contain restrictions on more than one member of CGBtype boards serving on the new corporations' boards of directors. ${ }^{148}$

Clearly some rules are needed to give direction to the economic development aspects of the program. It is also apparent that waiver of these rules is pessible in appropriate circumstances. ${ }^{149}$ These Model Cities rules are much less restrictive than those of other federal programs. Unfortunately, however, there is insufficient recognition of the potential of flexibility in providing venture capital for economic development activities. Such flexibility seems not only consistent with but mandated by a bloc grant program such as Model Cities. But the critical need is for venture capital to start businesses. If controls are to be imposed, they should be related to the capacity and potential of the minority entrepreneur development organization. Due regard should be given to the need to provide appropriate technical assistance to assure the best opportunity for the enterprise to succeed. Most loans involved here are essentially grants, given the high potential for failure. ${ }^{150}$ There seems little reason to hold two Swords of Damocles over the minority businessman's head. Failure itself should be enough without the threat of long term debt or the need for recourse to bankruptcy. If there is to be risk, the government is in the best position to assume it. The regulations should not be there so much to protect the money as to try to assure that the endeavor has the optimum potential for success. If any measuring standard is to be used, it should be this one.

\footnotetext{
${ }^{145}$ CDA Letter Ioc, supra note 97 , at 3.

${ }^{146} \mathrm{Id}$.

${ }^{167} I d$. at 6.

${ }^{148}$ HUD, CDA Letter Iod, MC3135.I Supp. 3 (Nov. 1970).

${ }^{169}$ The Deputy Assistant Secretary of the Model Cities Administration indicated some flexibility by stating that use of existing corporations was required, "except in unusual cases." Baida, supra note 138.

${ }^{200}$ Because chances for repayment of high risk, inner-city business or personal loans are often not great, such loans should be viewed as grants. One might wonder about why there was so much concern expressed in CDA Letter IOc and in the CUOF case over use of grants rather than loans.
} 


\section{CoNCLUSION}

The referencing of various federal rules and regulations to a series of games should not prevent recognition of the necessity for appropriate controls over use of federal funds for minority economic development. Since funds are limited and their utilization should maximize their effectiveness, recipients should evidence a reasonable possibility of success in the endeavor to be undertaken. Projects should be feasible, reasonable documentation of the use of funds should be required, and technical assistance should be available from both the public and the private sector. What has evolved for most programs, however, is a set of restrictions which have become so complex that they do not function as controls but take the appearance of a succession of games to be imposed upon the intended beneficiaries.

There are understandable reasons for the development of the mass of constraints which are applied to these programs. Perhaps the primary one stems from the fear of reaction by Congress when exercising its oversight function, particularly by the applicable appropriations subcommittees. Presentations to these committees for continuation of program funding often emphasize criteria insufficiently related to the purpose for which the legislation was enacted. In its appropriate overseer's role, moreover, Congress is especially sensitive to misapplication and malfeasance regarding these funds. Since most programs have had limited success, Congressional expectations for program effectiveness are not high. Therefore, mismanagement (in terms of legislative objectives), inefficiency, delay, and ineffectiveness are seemingly only of secondary concern to Congress. New criteria should be considered when reporting to Congress-those which have some tangible relationship to program objectives. Many of these are high-risk programs, a fact which should be clearly and openly stated to these subcommittees. Success should be measured by the number of opportunities provided rather than the number of safe loans made. Similarly, an honest estimate of the lead-time necessary before attempting to measure success should be the rule, not the exception, in testimony before committees. As thus described, the problem is one which must be mutually ascribed to Congress and the agency administrators. In the last analysis, however, the administrators can do much to sway the congressional attitudes if they take forthright positions concerning necessary changes.

There is a related cause of much of the recourse to gamesmanship in the executive branch, often denoted as "bureaucratic tendencies." Success is measured by not making mistakes, by delaying decisions, by recourse to the private sector to make the determination, and by careful, extended consultation to spread the risk of failure. Such problems are endemic to bureaucracies generally and are not limited solely to economic development programs.

The majority of these economic development programs are administerec locally. It is fitting that responsibility for the program should be placed on those persons at the local level who must operate it. Advice and counseling should be provided, but success in development activities can be built in only if local administrators and 
minority businessmen are allowed more freedom. In most circumstances, the federal administrator may delegate responsibility to the recipients of the funds. In effect, Congress has asked that program administrators force "the horse to drink," whereas, it should be sufficient if they simply "bring him to the water."

Inherent in the enactment of all of these federal programs is the fact that the private sector has not been able to revive the depressed economic condition of the inner cities. There seems little to be gained by forcing private involvement. If there must be budgetary "tactics," a roo per cent guarantee along with a small incentive fee should serve that purpose, while placing the risk with the government, which in the final analysis is the only body which can and should take it. By acknowledging this role and proceeding to make the effort as successful as possible, the government can obviate, or at least reduce, the elaborate system of games that now exists.

At a minimum, the following list of rather simplified recommendations should be considered in testing the appropriateness of program requirements:

(I) controls should relate to inoreasing opportunities for participation and success, not solely to safeguarding funds;

(2) mistakes should be permitted and assistance in correcting them should be provided (the government makes many of them);

(3) minority businessmen should be allowed independence and not be forced to take "partners" unnecessarily;

(4) sufficient funds to permit success should be provided if financial support is given;

(5) quantum changes should not be expected overnight;

(6) success in administration of programs should be judged on the effectiveness the program has had in accomplishing statutory objectives;

(7) persons who administer programs should where possible have applicable experience (perhaps the best use of the SBA SCORE program would be to advise the SBA administrators first, and applicants second);

(8) an applicant for financial assistance should be judged on his capacity, not on the amount of funds he has accumulated to date;

(9) the number of reviews (and resulting delays) should be drastically reduced by reliance on post-audit procedures;

(Io) where the rules must be changed, proper procedures should be used and the changes applied prospectively;

(II) flexible use of funds (including pyramiding of support) should be possible; and

(I2) the government should be the risk-taker of last resort. 